\title{
Tinjauan Yuridis Penagihan Hutang Dengan Penyebaran Data Diri Di Media Sosial
}

\author{
Sandro Wahyu Permadi dan Saiful Bahri \\ Magister Ilmu Hukum Universitas Brawijaya Malang Jawa Timur Indonesia \\ Jln. Veteran, Ketawanggede, Lowokwaru, Malang, Jawa Timur, Indonesia \\ Sandrowahyu4@gmail.com; saifulbahri442@gmail.com
}

Received: 20 Desember 2020; Accepted: 24 Desember 2020; Published: 31 Januari 2021

DOI: 10.20885/iustum.vol29.iss1.art2

\begin{abstract}
This study aims to identify, describe and analyze debt collection by damaging the reputation of debt owners on social media associated with violations of criminal law in the Criminal Code (KUHP) and violations of law in the Law on Information and Electronic Transactions (UU ITE). The research method uses is a normative juridical method with a statutory approach. The results of this study conclude that many people conduct debt collection through social media with the aim of being known by the public. This act has the risk of violating the law such as defamation which is regulated in the ITE Law. The ITE Law is seen as a threat to silence freedom of expression on the internet. If you damage the reputation of the debtor on social media, you can feel ashmed of the truth it should be stated in Article 310 of the Criminal Code on insult, rathee than UU ITE. It is hoped that law enforcement officers will act wiser in applying the articles that will be suspected with the argument that the origin of this defamation norm comes from the Criminal Code.
\end{abstract}

Key Words: debt collection, dissemination of personal data, social media.

\section{Abstrak}

Penelitian ini bertujuan untuk mengidentifikasi, mendeskripsikan dan menganalisis penagihan hutang dengan merusak reputasi pemilik hutang di media sosial dikaitkan dengan pelanggaran hukum pidana dalam Kitab Undang-Undang Hukum Pidana (KUHP) dan pelanggaran hukum dalam Undang-Undang tentang Informasi dan Transaksi Elektronik (UU ITE). Metode penelitian yang dipakai oleh penulis menggunakan metode penelitian yuridis normatif dengan pendekatan perundang-undangan. Hasil dari penelitian ini menyimpulkan bahwa banyak masyarakat melakukan penagihan hutang melalui sosial media dengan tujuannya diketahui oleh masyarakat umum. Perbuatan ini mempunyai resiko masuk pelanggaran hukum seperti pencemaran nama baik yang di atur dalam UU ITE. UU ITE dianggap sebagai ancaman untuk membungkam kebebasan berekspresi di internet. Apabila merusak reputasi pemilik hutang di media sosial yang dapat menyebabkan dampak rasa malu terhadap kebenaran yang ada, seharusnya merujuk dalam pasal 310 KUHP terkait penghinaan, dari pada UU ITE. Diharapkan aparat penegak hukum lebih bijak dalam menenerapkan pasal yang akan disangkakan dengan dalil bahwa asal mula adanya norma pencemaran nama baik ini berasal pada KUHP.

Kata-kata Kunci: Penagihan hutang; penyebaran data diri; sosial media 


\section{Pendahuluan}

Komunikasi merupakan alat yang digunakan dalam melakukan transfer kepentingan hidup bagi setiap NaturlijkPersoon. Hal ini berkaitan erat adagium Aristoteles yang menyebutnya manusia sebagai zoonpoliticon, artinya komunikasi merupakan kunci utama subjek hukum dalam melakukan perilaku, baik dalam menjalin hubungan yang menimbulkan kesepakatan dalam komunikasi maupun hubungan yang sedang diinginkan dalam setiap subjek hukum.

Jika ditarik dari kemerdekaan sampai dengan saat ini maka perkembangan komunikasi sangatlah pesat atau dalam bahasa yang khusus dapat diucapkan dengan signifikan, dimana komunikasi bisa dilakukan dengan menggunakan alat telekomunikasi yang sampai saat ini sudah secara independen dapat digunakan oleh setiap orang dan dimanapun sesuai dengan kebutuhan. Sehingga pada saat ini Verbintenis yang dulunya dilakukan dengan tatap muka, kini dilakukan dengan menggunakan alat telekomunikasi sesuai dengan kebutuhan dan dimanapun sesuai dengan kepentingan para pihak. Akan tetapi di lain sisi, perubahan yang sangat pesat juga melahirkan tanggungjawab dan akibat yang harus diperhatikan kepada setiap NaturlijkPersoon terutama pada Pemerintah.

Kemajuan teknologi yang di luar kendali negara Indonesia ini, dapat dijumpai dalam berbagai macam laman maupun aplikasi ilegal dan perjanjian yang didasarkan dengan perjanjian yang dilandaskan pada sistem Anglosaxon yang marak beredar pada situs android dan IOS. Di satu sisi memberikan kemudahan bagi penggunanya akan tetapi pada sisi lain memberikan akibat dan pengaturan terhadap perkembangan teknologi tersebut. Dengan kemajuan teknologi yang semakin hari semakin cepat ini mengakibatkan banyak perubahan terhadap sebuah negara, tidak terkecuali juga di Indonesia. Dinamika dengan adanya teknologi informasi ini mengalami perkembangan yang sangat pesat. ${ }^{1}$

Kecenderungan berkembangnnya teknologi berkosekuensi membawa berbagai macam implikasi yang harus segera diantisipasi dan diwaspadai. Oleh karenanya, memunculkan problematika baru jika di media sering dijumpai

${ }^{1}$ Daryanto Setiawan, "Dampak Perkembangan Teknologi Informasi dan Komunikasi Terhadap Budaya Impact of Information Technology Development and Communicationon Culture", SIMBOLIKA Vol. 4 No. 1, April 2018, hlm. 63. 
beberapa kelompok masyarakat dengan opini dan argumen yang berbeda pendapat. $^{2}$

Perkembangan teknologi informasi berdampak pada revolusi bentuk kejahatan yang konvensional menjadi lebih modern. Jenis kegiatannya mungkin sama, namun dengan media yang berbeda yaitu dalam hal ini internet, suatu kejahatan akan lebih sulit diusut, diproses, dan diadili melalui penyalahgunaan media internet. Di Indonesia, masalah yang terjadi khususnya di media sosial juga bisa dikatakan sangat banyak. Dengan banyaknya pengguna media sosial bagi kalangan masyakat Indonesia tentunya mulai mendapatkan pengaruh dalam penggunaannya. Oleh karenanya, tidaklah mengherankan apabila banyak bermunculan kasus-kasus yang berhubungan dengan dunia maya tersebut. ${ }^{3}$

Perkembangan masyarakat merupakan akibat dari adannya kebiasaan (Custom) yang berada dalam masyarakat. Hal ini senada dengan hukum yang berkembang sesuai dengan dinamika perkembangan masayarakat sesuai dengan kebiasaan. Hal ini merupakan wujud dari statis hukum yang ditandai dengan ciri hukum yang tertulis, sehingga hukum itu akan tertinggal zaman dengan modernisasi yang ada dalam kehidupan sekarang

Masyarakat hukum selalu berkembang, ini juga tidak terlepas dari hukum itu sendiri yang selalu dinamis dan tidak stagnan. Hukum selalu menjawab tantangan perubahan sosial, pun demikian juga dengan masyarakat Indonesia. ${ }^{4}$ Perkembangan terjadi juga tidak lepas dari dunia elektronik yang menyebabkan masyarakat mengikutinya. Tidak luput pula dari permasalahan hutang piutang. Biasanya, kasus hutang-piutang masuk dalam ranahnya hukum perdata. Seiring berjalannya waktu kasus tersebut berubah haluan jika penyampaiannya atau penagihannya dirasa kurang tepat oleh si peminjam hutang.

KUHP merupakan norma hukum yang memberikan rule of law terhadap masyarakat baik dalam kontek naturlijkpersoon dan rechtpersoon dalam pembatasan perbuatan yang melawan hukum dan penjaminan hidup masyarakat. Salah satu

\footnotetext{
2 Rini Retno Winarni, “Efektivitas Penerapan Undang-Undang ITE Dalam Tindak Pidana Cyber Crime”, Hukum Dan Dinamika Masyarakat Vol.14, No.1, Oktober 2016, hlm. 17

${ }^{3}$ Hetty Hassanah, “Tindak Pidana Perjudian Melalui Internet (Internet Gambling) Ditinjau Dari UndangUndang Nomor 11 Tahun 2008 Tentang Informasi Dan Transaksi Elektronik”, Majalab Ilmiab UNIKOM Vol.8, No. 2, November 2016, hlm. 232.

${ }^{4}$ Rachmad Safa'at, Ilmu Hukum Di Tengah Arus Perubahan, Surya Pena Gemilang, Malang, 2016, hlm. 12.
} 
yang dilindungi yaitu perbuatan pencemaran nama baik, entah itu di dunia nyata maupun di sosial media. Tak heran belakangan sedang marak perbuatan tersebut dilakukan oleh segelintir orang. Seperti yang diketahui, bahwa pencermaran nama baik merupakan sebuah pelanggaran yang melanggar hak asasi manusia. Pencemaran nama baik digolongkan menjadi sebuah penghinaan atau juga fitnah tanpa dasar fakta dan dasar yang kuat.

Di dalam KUHP penghinaan bisa ditemui dalam Bab XVI tentang Penghinaan. Dalam KUHP tersebut dibahas tentang tindak pidana penghinaan yang diatur pada Pasal 310 sampai dengan 321 KUHP. Baik penghinaan yang dilakukan secara lisan maupun tulisan dengan cara menista, memfitnah, ataupun mengadu secara memfitnah diatur dalam Pasal 310 sampai dengan Pasal 321 KUHP. ${ }^{5}$ Tindak Pidana berkaitan dengan Pencemaran nama baik serta penghinaan juga bisa ditemui dalam Undang-Undang Nomor 32 Tahun 2002 tentang Penyiaran dan Undang-Undang Republik Indonesia Nomor 19 Tahun 2016 tentang Perubahan Atas Undang-Undang Nomor 11 Tahun 2008 tentang Informasi dan Transaksi Elektronik.

Adanya elemen undang-undang tersebut, pihak yang merasa kepentingannya atau perbuatannya difitnah atau dirugikan, maka undangundang tersebut dirasa ampuh untuk melaporkan perbuatan tersebut. Oleh sebab itu, akhir-akhir ini banyak sekali kasus tentang pencemaran nama baik yang terjadi khususnya perbuatan yang dilakukan di media sosial. Ada beberapa peristilahan yang dianut atau digunakan dalam peraturan perundang-undangan yang digunakan dalam menyebutkan tindak pidana penghinaan maupun pencemaran nama baik. Tetapi, untuk tindak pidana pencemaran nama baik yang melalui sosial media diatur sendiri dalam UU ITE karena dampak dari perilaku tersebut menyebabkan dapat diketahui secara global dibandingkan dengan pencemaran nama baik secara konvensional. Jika disampaikan melalui media sosial, dapat diketahui oleh berbagai penjuru dunia hanya dalam hitungan detik. Sehingga, dampak yang diakibatkan bisa demikian kompleks dan rumit.

5 Wildan Muchladun, “Tinjauan Yuridis Terhadap Tindakan Pidana Pencemaran Nama Baik”, Jurnal Ilmu Hukum Legal Opinion. Vol.3, No.6, 2015, hlm. 2. 
Salah satu contoh seperti pada kasus di Pengadilan Negeri (PN) Enrekang, Sulawesi Selatan (Sulsel), menjatuhkan hukuman 1 bulan penjara kepada Seorang ibu berinisial C (37) karena menagih utang lewat dinding Facebook (FB). Majelis hakim menyatakan C melakukan kejahatan UU Informasi dan Transaksi Elektronik (ITE). Hal itu tertuang dalam putusan PN Enrekang yang dilansir situs Mahkamah Agung (MA), Jumat (19/3/2021). Kasus bermula saat C menagih utang kepada Y secara kekeluargaan pada Desember 2019. Tapi cara itu tidak membuahkan hasil. Akhirnya C menulis di dinding akun FB Y.6 Di dalam amar putusannya berisi "Menyatakan Terdakwa telah terbukti secara sah dan meyakinkan bersalah melakukan tindak pidana 'dengan sengaja dan tanpa hak membuat dapat diaksesnya informasi elektronik yang bermuatan pencemaran nama baik' sebagaimana dalam dakwaan tunggal Penuntut Umum. Menjatuhkan pidana terhadap Terdakwa oleh karena itu dengan pidana penjara selama 1 bulan dan denda sejumlah Rp. 2.000.000,00 dengan ketentuan apabila denda tidak dibayar maka diganti dengan pidana kurungan selama 1 bulan," kata majelis yang diketuai Pungky Wibowo dengan anggota majelis Bagus Priyo Prasojo dan Zulkifli Rahman. ${ }^{7}$ Hal ini sangat menarik untuk dibedah karena kalau memang kejadian ini memang benar adanya, dan sesuai fakta yang ada maka boleh jadi perbuatan tersebut bisa untuk dihindari kedepannya.

Pada kasus tersebut, ada dua parameter yang harus dicermati dalam memahaminya. Pertama terhadap pihak pemberi hutang merasa dirugikan karena hutangnya tidak dibayarkan dengan beberapa proses penagihan yang tidak ditanggapi. Akan tetapi di lain sisi, si peminjam juga merasa dirugikan karena nama baiknya tercemar karena sudah disebarkan di sosial media. Banyak pro dan kontra oleh masyarakat luar dalam menanggapi kasus ini. Ada yang mendukung dan ada juga yang mencemooh karena perilaku tersebut sudah diluar kewajaran dalam menagih hutang. Terlebih apabila perbuatan tersebut tidak benar adanya.

6 Andi Saputra, 'Tagih Utang Via Dinding Facebook, Emak-emak di Sulsel Dibui 1 Bulan", https://news.detik.com/berita/d-5499536/tagih-utang-via-dinding-facebook-emak-emak-di-sulsel-dibui-1bulan, Diakses 01 Juli 2021.

${ }^{7}$ Ibid 
Ujaran kebencian dan penyebaran berita hoaks pada orang lain juga bisa menimbulkan pencemaran nama baik. Karena, yang dilontarkan hanyalah informasi-informasi yang tidak benar adanya dan bisa disebut memfitnah dan membuat dampak buruk bagi korban tersebut. ${ }^{8}$ Namun, juga jangan dilupakan bahwa konstitusi juga mengamanatkan kebebasan hak dan berpendapat. Ini merupakan hak dasar yang dimiliki oleh setiap individu yang melekat pada diri masing-masing individu. Hal ini sebagaimana yang tercantum dalam Pasal 28E ayat (3) Undang-Undang Dasar 1945 ialah sebagai berikut "Setiap orang berhak atas kebebasan berserikat, berkumpul, dan mengeluarkan pendapat". Disamping itu juga dimuat dalam ketentuan Pasal 28F Undang-Undang Dasar 1945 yang berbunyi "Setiap orang berhak untuk berkomunikasi dan memperoleh informasi untuk mengembangkan pribadi dan lingkungan sosialnya, serta berhak untuk mencari, memperoleh, memiliki, menyimpan, mengolah, dan menyampaikan informasi dengan menggunakan segala jenis saluran yang tersedia". Namun, meskipun negara ini sudah mengamanatkan kebebasan hak dan berpendapat. tapi ada batasan-batasan tertentu yang perlu dihindari, yaitu seperti yang tertera dalam bunyi Pasal 28J ayat (2) Undang-Undang Dasar 1945 "Dalam menjalankan hak dan kebebasannya, setiap orang wajib tunduk kepada pembatasan yang ditetapkan dengan Undang-Undang dengan maksud semata-mata untuk menjamin pengakuan serta penghormatan atas hak dan kebebasan orang lain untuk memenuhi tuntutan yang adil sesuai dengan pertimbangan moral, nilai-nili agama, kemanan, dan ketertiban umum dalam suatu masyarakat demokratis".

Pada analisis kasus di atas, hemat saya dalam melakukan penerapan pada pencemaraan nama baik yang didasarkan dalam fakta hukum yang ada patut dan runut sesuai dengan Pasal 310 KUHpidana tentang penghinaan, jikamana permasalahan hukum hanya dilakukan penggunaan dan penafsiran terhadap asas lex temporis delicti, maka sangat kontra diktif antara Pasal 310 KUHpidana dengan Undang-Undang ITE No. 11 Tahun 2008 tentang pencemaran nama baik yang dilihat dari tempat terjadinya tindak pidana pencemaran akan tetapi tidak merujuk pada lex temporis dimana sebab terjadinya tindak pidana ini dimulai

8 Fairuz Rhamdhatul Muthia dan Ridwan Arifin, "Kajian Hukum Pidana Pada Kasus Kejahatan Mayantara (Cybercrime) Dalam Perkara Pencemaran Nama Baik Di Indonesia”, Jurnal Hukum Vol. 5, No. 1, April 2019, hlm. 26. 
dengan sumber hukum berupa perjanjian (Traktat). Hal ini hanya semata-mata tidak didasarkan dengan pemeriksaan dan penggunaan daripada dasar hukum yang patut dan bersesuai dengan fakta hukum yang ada. Walaupun UU ITE No. 8 Tahun 2008 merupan lex spesialis, namun muara dari pencemaran nama baik terkodifikasi dalam KUHpidana salah satunya pada Pasal 310 KUHpidana. Sehingga lazim digunakan sebagaimana pencemaran yang terjadi dalam permasalahan hukum ini.

Berdasarkan pemaparan dari latar belakang tersebut, penulis melakukan penelitian ini dengan fenomena yang baru dalam hal pemenuhan kewajiban pembayaran hutang di media sosial. Dengan adanya kasus yang baru marak sekarang ini sehingga masih jarang diteliti dan sangat menarik untuk dikaji.

\section{Rumusan Masalah}

Berdasarkan latar belakang sebagaimana telah diruaikan di atas, maka penulis mengangkat permasalahan yaitu apakah pengrusakan data diri pemilik hutang di media sosial merupakan pelanggaran hukum pidana dalam KUHP ataukah pelanggaran hukum dalam Undang-undang ITE?

\section{Tujuan Penelitian}

Adapun tujuan dari penulisan ini ialah untuk mengidentifikasi, mendeskripsikan dan menganalisa penagihan hutang dengan merusak reputasi pemilik hutang di media sosial dikaitkan dengan pelanggaran hukum pidana dalam KUHP dan pelanggaran hukum dalam Undang-Undang ITE.

\section{Metode Peneletian}

Penelitian ini menggunakan metode yuridis normatif yaitu penelitian dengan fokus kajian mengenai penerapan kaidah-kaidah atau norma-norma dalam hukum positif. Pendekatan dalam penelitian ini yaitu pendekatan perundang-undangan. Jenis data yang dipakai dalam penelitian ini adalah bahan hukum primer meliputi peraturan perundang-undangan dan bahan hukum sekunder meliputi literatur dan tulisan ilmiah lainnya yang dapat menjelaskan terhadap permasalahan dalam penelitian ini. Metode Pengumpulan data yang 
dipakai yaitu studi pustaka. analisis data dalam penelitian ini dilakukan secara kualitatif.

\section{Hasil Penelitian dan Pembahasan}

\section{Penagihan Hutang dengan Merusak Reputasi Pemilik Hutang di Media Sosial}

Berkenaan dengan pembahasan ini penulis akan melakukan kualifikasi secara definitif terhadap sebab akibat problematika hukum ini. Kalau dilihat dalam hukum perdata, hutang merupakan suatu kegiatan pinjam meminjam. Dalam kehidupan bermasyarakat dan bernegara, hutang atau kegiatan pinjam meminjam merupakan hal yang lumrah terjadi. Khususnya dalam kehidupan masyarakat kegiatan pinjam meminjam uang sering dilakukan untuk kebutuhan hidupnya. Dalam hukum perdata pula pinjam meminjam diatur dalam Pasal 1754 KUH Perdata, yaitu "Pinjam meminjam ialah perjanjian dengan mana pihak yang satu memberikan kepada pihak yang lain suatu jumlah tertentu barang-barang yang menghabis karena pemakaian, dengan syarat bahwa pihak yang belakangan ini akan mengembalikan sejumlah yang sama dari macam dan keadaan yang sama pula. Dalam peraturan tersebut seseoarang yang meminjam uang ataupun barang harus mengembalikannya sesuai sejumlah yang di pinjamnya dan sesuai dengan waktu yang ditentukan."

Hutang piutang merupakan perjanjian antara pihak yang satu dengan pihak yang lainnya dan objek yang diperjanjikan pada umumnya adalah hutang. Kedudukan pihak yang satu sebagai pihak yang memberikan pinjaman, sedangkan pihak yang lain menerima pinjaman uang. Hutang yang dipinjamkan akan dikeembalikan dengan jangka waktu sesuai dengan yang diperjanjikannya. ${ }^{9}$ Dari kegiatan pinjam meminjam ini timbul apa yang disebut dengan perikatan. Dan perikatan timbul dari adanya perjanjian. Oleh sebab itu, dalam Pasal 1233 KUH Perdata disebutkan "tiap-tiap perikatan dilahirkan baik karena persetujuan, baik karena undang-undang". ${ }^{10}$ Oleh karena itu, suatu perikatan terjadi atas dasar dari diadakannya suatu perjanjian, dimana debitur berkenan atas suatu prestasi dan kreditur berhak atas suatu prestasi. Wujud dari prestasi itu sendiri ialah memberi

\footnotetext{
${ }_{9}$ Gatot Supramon, Perjanjian Hutang piutang, Kencana Premadamedia Grup, Jakarta, 2014, hlm. 29

${ }^{10}$ R. Soeroso, Perjanjian Dibawah Tangan, Sinar Grafika, Jakarta, 2011, hlm. 4
} 
sesuatu, berbuat sesuatu dan juga tidak berubat sesuatu. ${ }^{11}$ Sebagaimana seperti yang terdapat pada ketentuan Pasal 1234 KUH Perdata “Tiap-tiap perikatan adalah untuk memberikan sesuatu untuk berbuat sesuatu, atau untuk tidak berbuat sesuatu". jika dirunutkan pada ketentuan pada KUH Perdata sangat begitu menekankan untuk saling memenuhi kewajiban dalam perikatan. Hal ini berlaku antara debitur dan kreditur sama-sama berhak untuk melaksanakan dan juga memenuhi prestasinya.

Pada prinsipnya ada berbagai macam atau cara dalam penagihan hutang. Bisa dilakukan secara lisan atau secara tertulis. Seyogyanya dalam hal penagihan ini dilakukan secara baik-baik atau yang biasa dikenal dengan musyawarah. Namun, apabila tidak diindahkan dan atau apabila terjadi wanprestasi penagihan hutang bisa dilakukan dengan cara yang lainnya. Adapun yang dimaksud wanprestasi di sini ialah suatu keadaan yang dikarenakan kelalaian atau kesalahannya, debitur tidak dapat memenuhi prestasi seperti yang telah ditentukan dalam perjanjian dan bukan dalam keadaan memaksa adapun yang menyatakan bahwa wanprestasi adalah tidak memenuhi atau lalai melaksanakan kewajiban sebagaimana yang ditentukan dalam perjanjian yang dibuat antara kreditur dengan debitur ${ }^{12}$. Pada umumnya mulai terjadinya wanprestasi yaitu suatu wanprestasi baru terjadi jika debitur dinyatakan telah lalai untuk memenuhi prestasinya. Atau dengan kata lain, wanprestasi ada kalau debitur tidak dapat membuktikan bahwa ia telah melakukan wanprestasi itu di luar kesalahannya atau karena keadaan memaksa. Apabila dalam pelaksanaan pemenuhan prestasi tidak ditentukan tenggang waktunya, maka seorang kreditur dipandang perlu untuk memperingatkan atau menegur debitur agar ia memenuhi kewajibannya. Teguran ini disebut dengan somasi. Somasi ini merupakan salah satu bentuk atau cara yang bisa dilakukan oleh kreditur (Pemiutang) untuk memberikan teguran agar debitur (Pengutang) untuk memenuhi prestasinya atau mengembalikan hutangnya.

Seorang debitur baru dikatakan wanprestasi apabila ia telah diberikan somasi oleh kreditur atau Juru Sita. Somasi itu minimal telah dilakukan sebanyak

${ }^{11}$ Ficky Nento, “Tinjauan Hukum Hapusnya Perikatan Jual Beli Barang Menurut Kitab Undang-Undang Hukum Perdata", Lex Crimen Vol. V No. 6, Agustus 2016, hlm. 73.

12 Salim HS, Hukum Kontrak: Teori dan Teknik Penyusunan Kontrak, Sinar Grafika, Jakarta, 2010, hlm. 96. 
tiga kali oleh kreditur atau Juru sita. Apabila somasi itu tidak diindahkannya, maka kreditur berhak membawa persoalan itu ke pengadilan. Dan pengadilanlah yang akan memutuskan, apakah debitur wanprestasi atau tidak. ${ }^{13}$

Seiring dengan perkembangan jaman banyak masyarakat yang melakukan penagihan hutang melalui sosial media. Tentu saja hal ini bisa dikatakan alternatif atau cara apabila debitur (pengutang) tidak mengindahkan penagihan yang dilakukan oleh kreditur (pemiutang). Cara ini tentu bisa dikatakan salah atau juga bisa dikatakan benar. Tergantung mau memandang hal itu dari perspektif yang mana. Karena hal ini masih belum ada aturan hukum yang jelas mengenai perbuatan penagihan hutang di sosial media. Cara ini dilakukan tentu adalah tujuannya untuk supaya diketahui oleh masyarakat umum. Jadi tidak hanya sang penagih dan yang ditagih yang bisa mengetahui informasi penagihan tersebut tapi juga seluruh orang di seluruh dunia juga tentu akan bisa melihat dan membacanya. Hal tersebut bisa salah apabila terdapat unsur penghinaan dan juga unsur pencemaran nama baik. Namun, ini menjadi tarik ulur permasalahannya dari yang semula tujuannya untuk penagihan hutang dan bergeser menjadi sebuah penghinaan atau pencemaran nama baik. Tentu saja ini menjadi problematika bersama karena kegiatan penagihan hutang yang dilakukan di media sosial ini sering marak terjadi dan bahkan bisa terulang kembali dengan ditiru oleh masyarakat yang lainnya. Khususnya masyarakat awam mungkin tidak mengetahui efek yang ditimbulkan apabila penagihan ini dilakukan di sosial media. Namun, karena masih belum ada aturan yang jelas mengenai perbuatan seperti ini bisa dikatakan benar apabila maksud dan tujuannya yaitu untuk penegasan kembali untuk membayarkan atau mengembalikan uang/benda yang dipinjam. Sebab orang tidak mungkin serta merta menagih di sosial media, tentu saja sudah menagih secara baik-baik. Tapi kalau menagih secara baik-baik tidak dihiraukan dan bahkan tidak dibayar, tentu hal tersebut bisa bikin emosi sang pemberi hutang. Dan oleh sebab emosi itulah yang menyebabkan sehingga ia menagih di media sosial.

Ada dua kategori pencemaran yang bisa dilihat. Antara lain pencemaran tertulis dan juga penghinaan ringan. Dua kategori ini yang sering kali 
menyebabkan ketidakpahaman terhadap para pelaku pencemaran dan juga seringkali menujukkan paralelitas.

Ada tiga hal yang membedakan penghinaan biasa (defamation-diffimation) dengan penghinaan ringan, yang menimbulkan akibat hukum yang berbeda pula. Tiga hal tersebut ialah: ${ }^{14}$

1. Charge with and act or fact, yaitu mengenai adanya tuduhan dari pelaku. Tuduhan demikian merupakan suatu persyaratan bagi penghinaan biasa yang tidak dijumpai pada "penghinaan ringan".

2. Plea of justification, yaitu hal yang dapat diajukan pada penghinaan biasa jika penghinaan yang terkait tidak dipersyaratkan pada penghinaan ringan.

3. Proof of Truth, yaitu mengenai istilah pembuktian akan kebenaran dari tuduhan yang dimana dapat dikaitkan dengan Pasal 311 KUHP yang memperbolehkan adanya pembuktian apabila hakim memandang perlu untuk memeriksa apakah perbuatan terdakwa dilakukan demi kepentingan umum atau karena terpaksa untuk membela diri. Unsur kepentingan kepentingan umum atau karena terpaksa untuk membela diri memiliki makna yang sama dengan Pasal 310 ayat (3) KUHP sehingga dapat dijadikan landasan untuk membenarkan suatu tindakan penghinaan. Oleh sebab itu, ketika pelaku penghinaan menyadari bahwa dia melakukan penghinaan demi kepentingan umum (atau karena terpaksa membela diri), maka hakim memperkenankannya untuk membuktikan tentang kebenaran dari tuduhannya (proof of truth).

Penghinaan apabila dibagi berdasarkan ilmu hukum dapat dibedakan atas dua bagian, yaitu penghinaan materiil dan penghinaan formil. Yang dimaksud dengan penghinaan materiil adalah penghinaan yang isinya merupakan kenyataan atau fakta yang meliputi penyataan objektif (zakelijk) dalam kata-kata secara lisan ataupun tulisan. Hal ini menyebabkan isi dari penghinaan tersebut sebagai suatu faktor yang menentukan. ${ }^{15}$

Kejahatan di dunia maya atau yang lebih spesifik dalam sosial media merupakan kejahatan yang modern yang muncul seiring dengan perilaku manusia dan juga seiring perkembangan teknologi informasi. Kejahatan yang

14 Bima Guntara, "Legitimasi penyebaran informasi yang memeiliki muatan penghinaan dan/atau pencemaran nama baik dalam dalam pasal 310 KUHP dan dan Undang-undang Nomor 19 Tahun 2016 tentang perubahan atas Undang-undang Nomor 11 Tahun 2008 Tentang Informasi dan Transaksi Elektronik", Jurnal Surya Kencana Dua: Dinamika Masalah Hukum dan Keadilan Vol. 4 No. 2, Desember 2017, hlm. 250.

15 Ibid 
berada dalam dunia maya mempunyai karakteristik yang berbeda dengan kejahatan konvensional seperti yang terdapat dalam KUHP.

Sebagai salah satu fungsi diadakannya hukum pidana yaitu untuk memberikan suatu sanksi agar seseorang tidak melakukan perbuatan tindak pidana lagi. Hal ini tentunya merupakan sebuah penerapan dari teori pemidanaan dengan tujuan yang khusus. Meskipun hukum pidana telah diatur dalam Kitab Undang-Undang Hukum Pidana (KUHP), namun tidak semua bisa menjangkau semua kejahatan yang ada dan juga belum terpikirkan saat pembuatan undangundang hukum pidana. Hal inilah yang patut dan menjadi sebuah permasalahan yang patut untuk dikaji. ${ }^{16}$ Hal seperti ini sangat wajar, karena ahli hukum pidanapun itu sebenarnya bukan ahli ramal yang bisa memprediksi berbagai kejahatan dimasa yang akan datang. Membuat suatu undang-undang apapun khususnya dalam undang-undang hukum pidana bukanlah kegiatan meramal. Namun, selalu ada penyesuaian pola hidup masyarakat yang terus dinamis. Oleh sebab itu, hukum selalu mengikuti kemauan masyarakat, bukan masyarakat yang mengikuti kemauan hukum. Kewenangan hakimpun tiada kebenaran yang mutlak melainkan hakim akan melakukan pemeriksaan terhadap perkara yang diperiksannya dengan pertimbangan saksi, dan bukti yang saling menjalin satu dengan yang lainnya sehingga akan memutuskannya. Dengan demikian, apabia terdapat perbuatan yang dianggap biasa namun dapat dianggap perbuatan tercela karena dapat dianggap sebagai perbuatan yang dapat merusak reputasi seseorang.

Seperti yang disebutkan di atas, tentu saja mempunyai resiko apabila hal tersebut dilakukan resikonya bisa dilaporkan dengan jalur pidana seperti disebutkan pada latarbelakang diatas. Ancaman ini bisa dilakukan dengan adanya UU ITE. Tentunya hal ini sangat menarik karena kaitannya dengan sosial media. Hal tersebut bisa dikatakan penghinaan atau pencemaran nama baik, dimana sesuai dengan bunyi Pasal 27 ayat (3) Undang-Undang Nomor 11 Tahun 2008 tentang Informasi dan Transaksi Elektronik yang berbunyi “Setiap Orang dengan sengaja dan tanpa hak mendistribusikan dan/atau mentransmisikan dan/atau membuat dapat diaksesnya Informasi Elektronik dan/atau Dokumen Elektronik yang

\footnotetext{
16 Aris Hrdinanto, "Manfaat Analogi Dalam Hukum Pidana Untuk Mengatasi Kejahatan Yang Mengalami Modernisasi”, Yuridika Vol. 31 No. 2, Mei 2016, hlm. 221.
} 
memiliki muatan penghinaan dan/atau pencemaran nama baik". Bunyi pasal ini tidak terlepas dengan maraknya penghinaan/pencemaran nama baik yang sering dilakukan di media sosial. Hal ini juga untuk mengatur atau menjaga ketertiban dan keamanan masyarakat. Secara substansi, penghinaan atau pencemaran nama baik merupakan perbuatan yang menyerang kehormatan orang lain dan atau nama baik seseorang, sehingga menyebabkan nama baik seseorang tersebut merasa tercemar dan rusak. Oleh karena itu, maka dalam menentukan adanya penghinaan dari pencemaran nama baik perlu dipahami terlebih dahulu konteksnya. Apakah perbuatan itu dilakukan dengan kesengajaan atau perbuatan itu dilakukan untuk membela diri.

Untuk melaksanakan pemeriksaan di pengadilan sesuai dengan analogi gramatikal, maka menjadikan hal yang sangat utama dalam melakukan pemeriksaan di pengadilan melihat suatu permasalahan dengan melakukan penafsiran sebab akibat, dimana dalam kasuistis ini merupakan persengketaan ranah pidana yang terjadi karena adannya perjanjian yang dilakukan oleh kedua belah pihak melalui perjanjian utang-piutang. Dalam hal ini sudah diberikan kekuasaan kepada para pihak jikamana dalam melakukan prestasinya terdapat cidera janji maka dilakukan dengan pembatalan maupun penuntutan pemenuhan kewajibannya di pengadilan sesuai dengan pengaturan Pasal 1266 dan 1267 KUHperdata, sehingga akan memberikan kontraktual norma terhadap penyelesaian yang menggunakan dasar Hukum Pidana.

Di lain sisi, dalam hukum pidana memberikan irah-irah terhadap apa yang masuk dalam tindak pidana. Akan menjadikan sesuatu yang sangat berlebihan dan tidak ada keadilan dalam problematika dalam perkara ini. Jika dikaji dengan menggunakan dasar hukum yang ada penggunaan UU ITE No. 11 Tahun 2008 sangat kotradiktif terhadap muara Pasal 310 KUHP sendiri. Artinya dalam penerapan hukum yang dilakukan seharusnya menggunakan ranah hukum yang mengatur secara generalis kemudian ditarik pada dasar hukum yang spesialis. Kekhususan yang dimaktub adalah hukum yang mengatur secara spesifik, tepat sasaran dan efesien, sehingga akan memberikan makna keadilan, kemanfaatan dan kepastian hukum. 
Jika pencemaran nama baik dilakukan dalam media sosial merupakan delik aduan, maupun delik biasa yang kemudian dikerucutkan dalam Pasal 27 Undang-Undang ITE 2008 maka banyak hal yang menjadikan pertanyaan dan dasar yang digunakan dalam penerapan hukum tersebut. Seyogyanya dalam pencemaran nama baik yang lebih cenderung dalam penghinaan seharusnya masuk dalam Pasal 310 KUHpidana, hal ini dibuktikan dengan adanya tuduhan yang secara benar adanya tentang utang piutang yang tidak dilaksanakan pembayarannya oleh salah satu pihak dalam perjanjiannya.

Jika dikorelasikan dengan UU ITE tidak memberikan kejelasan sebab akibat pada problematika yang ada, pencemaran nama baik seperti yang dimaktubkan dalam Pasal 27 ayat (3) lebih memberikan keleluasaan kepadakhayalak ramai memberikan komentar kepada pihak yang berhutang dan secara tidak langsung merendahkan hak seseorang.

Kalau hanya melihat UU ITE tentu ini sangat parsial. Penghinaan atau pencemaran nama baik sebenarnya sudah terdapat dalam Kitab Undang-Undang hukum Pidana (KUHP). Di dalam KUHP sebenarnya sudah lengkap disajikan mengenai apa itu penghinaan dan pencemaran nama baik. Tentunya UU ITE bersifat khusus jika dilakukan di media sosial, namun penghinaan dan pencemaran nama baik tidak bisa dipisahkan dengan KUHP karena didalamnya termuat norma mengenai hal tersebut. Di dalam Pasal 310 ayat (1) dijelaskan, bahwa "Barangsiapa sengaja menyerang kehormtan atau nama baik seseorang dengan menuduhkan sesuatu hal, yang maksudnya terang supaya hal itu diketahui umum, diancam karena pencemaran dengan pidana penjara paling lama sembilan bulan atau pidana dengan paling banyak empat ribu lima ratus rupiah". Sehingga ada beberapa elemen yang harus dilengkapi kalau memang tindakan tersebut dikatakan sebagai pencemaran nama baik atau tidak. Unsur yang pertama yang harus terpenuhi ialah "dengan sengaja", kedua "menyerang kehormatan atau nama baik", yang ketiga "menuduh melakukan sesuatu perbuatan", yang keempat "menyiarkan tuduhan supaya diketahui oleh umum". Di dalam Pasal 310 KUHP ada lanjutannya yang menjadi satu kesatuan yang tidak bisa dipisahkan, yaitu seperti yang tertera dalam Pasal 310 ayat (3) KUHP yang berbunyi "Tidak merupakan pencemaran atau pencemaran tertulis, jika perbuatan jelas dilakukan demi kepentingan umum atau karena terpaksa untuk membela diri". Artinya 
kalau berbicara pencemaran nama baik, bicara penghinaan itu harus ada tuduhan. Apakah tuduhannya itu palsu atau tidak. Misal contoh, A menyebarkan di media sosial bahwa B meminjam motornya dan tidak dikembalikan setelah beragam cara penyampaian dan belum juga dikembalikan. Faktanya B memang meminjam motor A dan belum dikembalikan. Mensreanya atau niat jahatnya bukan untuk mempermalukan tapi supaya motor itu dikembalikan oleh B. Peminjaman motornya tidak menjadi persoalan, tapi pencemarannya dan penghinaannya yang menjadi persoalan apabila itu tidak bisa dibuktikan.

Menurut Putusan Mahkamah Konstitusi Nomor 50/PUU-VI/2008 penafsiran norma yang termuat dalam Pasal 27 ayat (3) Undang-Undang ITE mengenai penghinaan dan/ atau pencemaran nama baik tidak bisa dilepaskan dari genusnya yaitu norma hukum pidana yang termuat dalam Bab XVI tentang penghinaan yang termuat dalam Pasal 310 dan Pasal 311 KUHPidana, sehingga konstitusional Pasal 27 ayat (3) Undang-Undang ITE harus dikaitkan dengan Pasal 310 dan Pasal 311 KUHPidana. Dengan demikian, segala unsur tindak pidana pencemaran nama baik dalam Pasal 27 ayat (3) mengacu pada pemahaman dan esensi unsur pencemaran nama baik dari Pasal 310 dan 311 KUHPidana. ${ }^{17}$ Larangan mengenai penghinaan seperti yang dijelaskan dalam pasal a quo, sebenanya hal itu dibuat untuk dapat melindungi hak antar golongan. Karena pada dasarnya ketika akan memuat suatu informasi dalam media manapun harus mendapat suatu rekomendasi atau persetujuan dari yang bersangkutan, agar yang bersangkutan tidak merasa dirugikan dengan penyebaran informasi terebut sehingga perbuatan itu dapat dipertanggungjawabkan.

Apabila terjadi contoh seperti di atas, maka oleh Pasal 311 ayat (1) KUHP diberikan kesempatan membuktikan tuduhan. Isi pasal tersebut berbunyi "Jika yang melakukan kejahatan pencemaran atau pencemaran tertulis dibolehkan untuk membuktikan apa yang dituduhkan itu benar, tidak membuktikannya, dan tuduhan dilakuka bertentangan dengan apa yang diketahui, maka dia diancam melakukan fitnah dengan pidana penjara paing lama empat tahun". Jika dikonstruksikan dengan contoh yang sudah dipaparkan dan A bisa menghadirkan saksi-saksi bahwa memang hal

17 Alicia Lumenta, “Tinjauan Yuridis Terhadap Tindak Pidana Pencemaran Nama Baik Menurut KUHP Dan Undang-Undang Nomor 19 Tahun 2016 Tentang ITE”, Lex Crimen Vol. IX No. 1, Januari-Maret 2020, hlm. 26. 
tersebut sesuai faktanya, maka menurut hemat penulis tuduhan yang ditulis melalui media sosial tidak bisa dikatakan sebagai penghinaan maupun pencemaran nama baik. Sebagaimana dimaksud dalam Pasal 27 ayat (3) UU ITE. Sehingga pandangan penulis, pencemaran nama baik, penghinaan, itu tidak bisa dipisahkan antara UU ITE dengan Pasal 310 KUHP. Pasal 310 KUHP pun juga berkaitan dengan Pasal 311 ayat (1) KUHP yang memberikan kepada orang yang menuduh itu untuk membuktikan apakah tuduhannya itu benar, apakah tuduhannya itu palsu, apakah tuduhannya itu hanya mengada-ada

Hukum pidana merupakan sebuah celaan resmi masyarakat yang diformulasikan di dalam Undang-Undang. Dengan demikian, sebuah tindakan yang dilarang dalam hukum pidana merupakan suatu representasi dari adanya pelanggaran terhadap nilai-nilai yang berkembang dan hidup dalam masyarakat. Bisa juga dikatakan perbuatan tersebut yang diatur di dalam hukum pidana merupakan sebuah perbuatan yang dapat merugikan masyarakat. Tetapi tidak semua perbuatan yang dapat merugikan masyarakat dapat diatur juga dalam hukum pidana. Karena disebabkan oleh beberapa factor, misalnya seperti ada contoh dalam latar belakang di atas, yaitu sulitnya dalam hal untuk memformulasikan dengan benar dan tepat atau dalam prakteknya tidak dapat dilaksanakan dengan baik karena bersinggungan dengan beberapa hal yang dapat menyulitkan peradilan.

Perbuatan yang demikian ini masih sangat abstrak, dalam artian perbuatan yang bersifat anti sosial. Sehingga perlu untuk dibuatkan batasan-batasan yang jelas, sehingga nantinya dapat dijadikan sebuah pedoman kedepannya. Teoriteori ini mungkin dapat dijadikan sebagai dasar atau justifikasi kriminalisasi. Diantaranya teori moral dan juga teori liberal individualistik.

Menurut teori moral, antara hukum pidana dengan dimensi moral merupakan dua hal yang sangat dekat. Kriminalisasi suatu perbuatan dapat didasarkan kepada nilai-nilai moral yang hidup dalam masyarakat. Perbuatanperbuatan yang bersifat immoral dapat dilegalisasi ke dalam undang-undang menjadi sebuah tindak pidana. Jika suatu perbuatan immoral tidak dikriminalisasi maka yang akan terjadi adalah ketegangan antara moral dengan hukum pidana. Teori ini dapat menjadi justifikasi kriminalisasi delik pencemaran nama baik di Indonesia sesuai dengan kultur masyarakat Indonesia yang masih 
menjunjung tinggi budaya timur. Dalam negara yang masih menjunjung budaya timur, perbuatan yang mengandung pencemaran nama baik seperti menghina, memfitnah atau yang serupa dengan itu sangat bertentangan dengan sopan santun, sehingga perbuatan tersebut bersifat anti-sosial dan harus dikriminalisasi. ${ }^{18}$ Selain teori moral, liberal individualistik juga dapat dijadikan dasar justifikasi kriminalisasi delik pencemaran nama baik. Teori liberal individualistik yang berpijak kepada harm to society memberikan rambu-rambu terhadap pembatasan kebebasan warga negara. Menurut teori ini, kekuasaan negara tidak dapat membatasi kebebasan warga negara kecuali jika perbuatannya merugikan orang lain, sehingga terhadap perbuatan yang merugikan ini negara berhak mengkriminalisasikan. ${ }^{19}$ Kerugian yang dimaksud tentunya bukan hanya kerugian yang bersifat materiil saja, melainkan juga immaterial. Dampak yang ditimbulkan terhadap perbuatan yang mengandung pencemaran nama baik lebih berupa kerugian immateriil, yaitu jatuhnya kehormatan, nama baik, harkat dan martabat seseorang. Kerugian yang demikian ini berdampak kepada hubungan sosial karena perbuatan tersebut dapat memberikan akibat berupa timbulnya stigma negatif bagi seseorang di masyarakat. Seseorang yang menjadi korban pencemaran nama baik ini bisa saja akan dijauhi atau dikucilkan dalam pergaulan masyarakat. ${ }^{20}$

\section{Pengaturan dalam KUHP dengan UU ITE terkait Pencemaran Nama Baik}

Pengaturan penyebaran informasi dalam Undang-Undang ITE, khususnya dalam hal yang mengandung muatan penghinaan atau pencemaran nama baik. Karena adanya perkembangan teknologi informasi, Undang-Undang ITE dibuat untuk mengikuti perkembangan tersebut sehingga apabila terdapat perbuatan melawan hukum yang terkait dengan ruang lingkup dunia cyber diharapkan pengaturan melalui Undang-Undang ITE dapat tepat kepada sasarannya. Oleh karena itulah, untuk melihat seberapa tepat pengaturan melalui Undang-Undang ITE tersebut dilakukanlah tinjauan secara tekstual untuk melihat seperti apakah

18 Ari Wibowo, “Kebijakan Kriminalisasi Delik Pencemaran Nama Baik Di Indonesia”, Pandecta Vol. 7 No. 1, Januari 2020, hlm. 6-7.

${ }^{19}$ Ibid

${ }^{20}$ Ibid 
batasan dari konsep penyebaran informasi dalam Undang-Undang ITE jika dibandingkan dengan KUHP. ${ }^{21}$

Aktivitas di internet tidak dapat dilepaskan dari faktor manusia dan akibat hukumnya juga bersinggungan dengan manusia di masyarakat yang berada dalam dunia fisik, maka kemudian muncul pemikiran tentang perlunya aturan hukum untuk mengatur aktivitas-aktivitas di dalam ruang maya (cyberspace) tersebut. Oleh karena karakteristik ini sangat berbeda, maka muncul pendapat pro dan kontra mengenai dapat atau tidaknya hukum konvensional yang mengatur aktivitas-aktivitas di dalam ruang maya. Hal ini akan menimbulkan perdebatan dalam pengaturannya. Secara umum, permasalahan pro dan kontra mengenai dapat atau tidaknya sistem hukum konvensional mengatur aktivitasaktivitas di cyberspace yaitu; 22

1. Karakteristik aktivitas-aktivitas di internet sebagai bagian dari teknologi informasi adalah lintas batas atau hubungan dunia menjadi tanpa batas sehingga tidak lagi tunduk pada batasan-batasan territorial dan menyebabkan perubahan ekonomi, sosial, teknologi dan budaya secara signifikan.

2. Sistem hukum konvensional yang justru bertumpu pada territorial, dianggap tidak cukup untuk memadai untuk menjawab permasalahanpermasalahan hukum yang baru timbul dan dimunculkan oleh aktivitasaktivitas manusia di dalam dunia ruang maya.

Konsep hukum mengenai penyebaran informasi, KUHP dapat didasarkan kepada verspreiden delicten yang berasal dari sistem hukum negara Belanda, maka dapat dikatakan bahwa konsep hukum mengenai pengaturan penyebaran informasi yang digunakan dalam KUHP adalah apabila seseorang menyebarkan sesuatu yang dilarang oleh hukum dalam ruang akses yang luas sehingga setiap orang dapat memperoleh sesuatu yang disebarkan tersebut. ${ }^{23}$

Undang-Undang Republik Indonesia Nomor 19 Tahun 2016 Atas Perubahan Undang-Undang Nomor 11 Tahun 2008 tentang Informasi dan Transaksi Elektronik adalah produk hukum yang mengatur permasalahan-permasalahan di dunia maya atau internet atau yang biasa orang sebut media sosial. Beberapa

${ }^{21}$ Loc. Cit., Bima Guntara, hlm. 252.

22 Suyanto Sidik, "Dampak Undang-Undang Informasi Dan Transaksi Elektronik (UU ITE) Terhadap Perubahan Hukum Dan Sosial Dalam Masyarakat”, Jurnal Ilmiah WIDYA, Vol. 1 No. 1, Mei-Juni 2013, hlm. 4.

${ }^{23}$ Ibid 
pasal dalam UU ITE yang dilarang untuk dilanggar di dalam memanfaatkan dunia maya atau perbuatan yang dilarang dilakukan dalam mengakses di dunia internet adalah Pasal 27, Pasal 28, Pasal 29.

Terkait pencemaran nama baik dengan menggunakan pasal-pasal KUHP untuk menjerat pelaku pencemaran nama baik melalui internet, oleh sebagian ahli hukum ada yang menyatakan bahwa KUHP tidak dapat dterapaka, namun tak sedikit juga para ahli hukum lain yang menganggapnya KUHP dapat menjangkaunya. Bagi kubu yang pro Pasal 27 ayat (3) UU ITE, pasal ini berfungsi untuk melindungi hak orang yang dicermakan nama baiknya atau dihina melalui media internet. Bagi kubu yang kontra, pasal ini rumusannya dianggap sebagai jaring empuk untuk membungkan kritik atau bahkan kebebasan berkespresi di internet. Dari beberapa ahli yang mengemukakan pendapatnya terhadap hal ini antara lain:24

a. Edmon Makarim menjelaskan bahwasanya Pasal 27 ayat (3) UU ITE haruslah tetap ada agar sistem elektronik tidak menjadi ajang untuk saling mencemarkan nama baik karena dampaknya bersifat masif. Untuk menggunakan pasal ini, penyidik dan jaksa penuntut umum haruslah dapat membuktikan dua unsur obyektif, yaitu dengan sengaja dan tanpa hak.

b. Muhammad Salahuddien Manggalany, pada pokoknya M. Salahuddien tidak sepakat dengan argumentasi bahwa pasal pencemaran (defamation) sering digunakan untuk membungkam kritik masyarakat terutama di alam reformasi yang sangat terbuka selama ini. Untuk membuktikan dugaan tersebut harus didukung data yang kuat dan lengkap. Ancaman dalam UU ITE lebih berat dari KUHAP adalah karena pertimbangan dampak kerusakan yang dihasilkan oleh pencemaran dengan menggunakan teknologi informasi yang bersifat meluas, jangka panjang dan dapat berulang sehingga kerugian yang dialami korban jauh lebih besar (efek amplifikasi) dibandingkan apabila pencemaran terjadi melalui saluran konvensional.

Sementara itu, pada kubu yang mempertanyakan rumusan pasal tersebut, alasan utamanya karena pasal ini memiliki ketidakjelasan rumusan pasal sehingga sangat rentan terjadi multiinterpretasi. Beberapa pendapat tersebut diantaranya:

\footnotetext{
24 Sam Ardi, "Perdebatan Pasal 27 ayat 3 UU ITE”, https://samardi.wordpress.com/2011/07/15/perdebatan-pasal-27-ayat-3-uu-ite/, Diakses tanggal 15 Desember 2020.
} 
a. Sutan Remy Sjahdeini, pada pokoknya mempertanyakan pencantuman frasa "tanpa hak" dalam pasal tersebut. Alasannya adalah apakah ada otoritas resmi yang memiliki otoritas resmi untuk mengizinkan pihak tertentu untuk mendistribusikan dan/atau mentransmisikan dan/atau membuat dapat diaksesnya Informasi Elektronik dan/atau Dokumen Elektronik. Tidak mungkin sifat melawan hukum dari perbuatanperbuatan tersebut menjadi terhapus karena ada pihak yang dapat memberikan hak kepada pihak lain untuk mendistribusikan dan/atau mentransmisikan dan/atau membuat dapat diaksesnya Informasi Elektronik dan/atau Dokumen Elektronik yang memuat penghinaan dan/atau pencemaran nama baik, dengan kata lain rumusan tersebut dibuat berlebihan.

b. Adami Chazawi, pada pokoknya berpendapat andaikata tidak dirumuskan sebagai penghinaan lex specialis, penghinaan melalui media elektronik (internet) tetap bisa menggunakan pasal-pasal penghinaan di KUHP yang sesuai dengan kasusnya, dengan cara menafsirkan misalnya berdasarkan tujuan dari dibentuknya kejahatan penghinaan atau yang lebih ekstrim dengan penafsiran ekstensif. Dengan dicantumkan/disebutkan frasa "pencemaran dan/atau penghinaan", bisa terjadi salah menafsirkan seolah-olah bentuk-bentuk penghinaan selain pencemaran - tidak masuk dalam pengertian/cakupan tindak pidana Pasal 27 ayat (3) UU ITE. Kedelapan bentuk penghinaan (dalam KUHP) jika dilakukan dengan menggunakan sarana eletronik diancam pidana yang sama yakni maksimum 6 tahun penjara dan/atau denda maksimum Rp. 1.000.000.000,00. Padahal jika kembali pada azas penghinaan yang dibedabedakan menjadi 8 macam yang diancam dengan pidana yang berbedabeda, artinya dibebani tanggungjawab sendiri-sendiri secara berbeda-beda berat ringannya. Lebih fatal lagi jika pertanggungjawaban pidana pada penghinaan ringan disamakan dengan fitnah oleh UU ITE dengan ancaman pidana yang sama, yakni maksimum 6 tahun penjara.

Dari adanya beberapa pendapat di atas dapat diambil garis besarnya bahwa memang terdapat perbedaan pendapat mengenai eksistensi keberadaan pasal penghinaan dan pencemaran nama baik. karena pada prinsipnya didalam objek inilah terdapat kepentingan hukum yang hendak bahkan harus dindungi dalam tindak pidna yang bersangkutan. Suatu perbuatan tndak pdana pada hakikatnya selalu berhubungan erat dengan kepentingan hukum yang mesti dilindungi. seperti contohnya dalam Pasal 310 KUHP tentang pencemaran, objek hukumnya dalam tindak pidana adalah "kehormatan dan juga nama baik" orang dengan kepentingan orang lain yang harus dilindungi oleh rumusan pasal a quo. Maksud dari melindung ini yatu melindung dua objek hukum, yaitu melindungi 
kepentingan hukum terhadap nama baik serta melindungi terhadap kehormatan orang. Bahkan perlindungan terhadap orang yang sudah meninggalpun juga patut untuk dilindungi. Kepentingan yang seperti ini patut dan juga perlu untuk dijaga dan juga dipertahankan dalam hukum.

Berdasarkan hal di atas, kaidah hukum Pencemaran Nama Baik itu tidak hanya diakomodir oleh KUHP tetapi juga produk hukum lain di luar KUHP yang juga menerapkan sanksi pidana, di mana produk hukum itu sebagaimana disebutkan diatas ialah UU ITE itu sendiri. Pasal Pencemaran Nama Baik dalam UU ITE ini memang menimbulkan kontroversi. Bahkan, dinilai hal ini merupakan kemunculan pasal karet atau hatzaaiartikelen gaya baru. Tidak hanya itu saja, pasal ini juga dirasa lebih berat ketimbang pasal pencemaran nama baik yang berada dalam KUHP. Lihat saja didalam sanksi yang berada dalam KUHP dan juga sanksi yang berada dalam UU ITE. Di dalam UU ITE ancaman pidananya masimal 6 (enam) tahun penjara. Sedangkan ancaman pidana yang berada dalam KUHP, ancamanny maksimum 4 tahum penjara. Bahkan di dalam Pasal 310 KUHP hanya memberikan ancaman hukuman 9 bulan penjara. Jadi, dengan substansi tuduhannya sama, namun dalam UU ITE sanksi hukuman yang diberikan lebih berat ketimbang KUHP.

\section{Penutup}

Penerapan dalam melakukan sanksi maupun hukuman yang diberikan kepada orang, maka harus didasarkan dengan dasar hukum yang mengaturnnya. Hal ini dikolerasikan dengan asas hukum pidana yang menyatakan seseorang tidak dapat dipidana/dihukum ketika belum terbukti kesalahannya "nullum deliktum nulla poena sine praevia lege poenalli". Sesuai dengan maksud Penghinaan yang dilakukan seseorang kepada orang yang disebutkan adalah termuara pada Pasal 310 KUPidana yang secara jelas maksud untuk diketahui publik dengan adannya utang piutang serta benar adannya masuk dalam rumpun delik biasa, sedangkan dalam Undang-undang ITE pencemaran nama baik maupun pencemaran dimasukkan dalam delik aduan. Artinya tiada kekhususan yang memberikan penjelasan pencemaran dalam arti Penghinaan dan Pencemaran nama atas dasar Fitnah ataupun tuduhan palsu. Undang-undang ITE No. 19 
tahun 2016 atas perubahan UU ITE No. 11 tahun 2008 dewasa ini memberikan kemultitafsiran terhadap maksud pencemaran nama baik.

Selanjutnnya maka perlu dilakukan pemuliaan terhadap Pasal 310 KUHpidana, secara jelas memberikan maktub terhadap Penghinaan, Pencemaran dengan Fitnah atau kabar tidak benar, serta rumpun pencemaran yang diatur hingga Pasal 315 KUHpidana. Sehingga memberikan argumentasi hukum bahwa sahnnya pencemaran yang dilakukan ke dalam media sosial yang memberikan dampak rasa malu terhadap kebenaran yang ada, maka masuk kedalam Pasal 310 KUHpidana yang merujuk pada Penghinaan. Untuk itu menjadikan rule of law terhadap pencemaran nama baik (Penghinaan) ini haruslah masuk dalam 310 KUHpidana, dimana unsur dalam pasal tersebut memenuhi rangkaian fakta yang terjadi. Sehingga patut dan secara terang benderang diberlakukan Pasal 310 KUHpidana sebagaimana yang terjadi.

\section{Daftar Pustaka}

\section{Buku}

HS, Salim, Hukum Kontrak: Teori dan Teknik Penyusunan Kontrak, Sinar Grafika, Jakarta, 2010.

Safa'at, Rachmad, Ilmu Hukum Di Tengah Arus Perubahan, Surya Pena Gemilang, Malang, 2016.

Soeroso, R, Perjanjian Dibawah Tangan, Sinar Grafika, Jakarta, 2011

Supramon, Gatot, Perjanjian Hutang piutang, Kencana Premadamedia Grup, Jakarta, 2014.

\section{Jurnal}

Alicia Lumenta, "Tinjauan yuridis terhadap tindak pidana pencemaran nama baik menurut KUHP dan Undang-Undang Nomor 19 Tahun 2016 Tentang ITE", Lex Crimen Vol. IX No. 1, Januari-Maret 2020.

Ari Wibowo, "Kebijakan kriminalisasi delik pencemaran nama baik di Indonesia", Pandecta Vol. 7 No. 1, Januari 2020.

Aris Hardinanto, "manfaat analogi dalam hukum pidana untuk mengatasi kejahatan yang mengalami modernisasi", Yuridika Vol. 31 No. 2, Mei 2016.

Bima Guntara, "Legitimasi penyebaran informasi yang memeiliki muatan penghinaan dan/atau pencemaran nama baik dalam dalam pasal 310 KUHP dan dan Undang-undang Nomor 19 Tahun 2016 tentang perubahan atas Undang-undang Nomor 11 Tahun 2008 Tentang 
Informasi dan Transaksi Elektronik", Jurnal Surya Kencana Dua: Dinamika Masalah Hukum dan Keadilan Vol. 4 No. 2, Desember 2017.

Daryanto Setiawan, “Dampak Perkembangan Teknologi Informasi dan Komunikasi Terhadap Budaya Impact of Information Technology Development and Communicationon Culture", SIMBOLIKA Vol. 4 No. 1, April 2018.

Hetty Hassanah, “Tindak Pidana Perjudian Melalui Internet (Internet Gambling) Ditinjau Dari Undang-Undang Nomor 11 Tahun 2008 Tentang Informasi Dan Transaksi Elektronik", Majalah Ilmiah UNIKOM Vol.8, No. 2, November 2016.

Ridwan Arifin dan Fairuz Rhamdhatul Muthia, "Kajian Hukum Pidana Pada Kasus Kejahatan Mayantara(Cybercrime) Dalam Perkara Pencemaran Nama Baik Di Indonesia", Jurnal Hukum, Vol. 5, No. 1, April 2019.

Rini Retno Winarni, "Efektivitas Penerapan Undang - Undang Ite Dalam Tindak Pidana Cyber Crime", Hukum Dan Dinamika Masyarakat Vol.14, No.1, Oktober 2016.

Suyanto Sidik, "Dampak undang-undang informasi dan transaksi elektronik (uu ite) terhadap perubahan hukum dan sosial dalam masyarakat", Jurnal Ilmiah WIDYA, Vol. 1 No. 1, Mei-Juni 2013.

Wildan Muchladun, “Tinjauan Yuridis Terhadap Tindakan Pidana Pencemaran Nama Baik", Jurnal Ilmu Hukum Legal Opinion. Vol.3, No.6, 2015.

\section{Internet}

"Tagih Utang di Instagram, Seorang Wanita Malah Dipolisikan", https://www.cnnindonesia.com/nasional/20200107173522-12463232/tagih-utang-di-instagram-seorang-wanita-malah-dipolisikan, Diakses tanggal 14 Desember 2020.

Sam Ardi, "Perdebatan Pasal 27 ayat 3 UU ITE", https://samardi.wordpress.com/2011/07/15/perdebatan-pasal-27-ayat3-uu-ite/, Diakses tanggal 15 Desember 2020. 